\title{
VECTORS OF DEVELOPMENT OF EDUCATIONAL AND METHODOLOGICAL COMPETENCE OF THE MODERN TEACHER IN THE CONDITIONS OF MODERNIZATION OF VOCATIONAL EDUCATION OF UKRAINE
}

\author{
Svitlana Shevchuk, \\ SIHE “University of Education Management" \\ NAPS of Ukraine, Senior Lecturer, \\ Professional Education Methods, \\ Social and Humanitarian Disciplines Department Bila Tserkva \\ Institute of Continuous Professional Education, \\ Bila Tserkva, Kyiv region, Ukraine \\ https://orcid.org/0000-0001-6260-3323 \\ shevchukbinpo@ukr.net \\ Volodymyr Kulishov, \\ SIHE "University of Education Management" \\ NAPS of Ukraine, Associate Professor, \\ Professional Education Methods, \\ Social and Humanitarian Disciplines Department Bila Tserkva \\ Institute of Continuous Professional Education \\ Candidate of Pedagogical Sciences, \\ Bila Tserkva, Kyiv region, Ukraine \\ https://orcid.org/0000-0003-3262-796X \\ kulishov_04@ukr.net \\ Tetiana Shchypska, \\ SIHE "University of Education Management" \\ NAPS of Ukraine, Senior Lecturer, \\ Professional Education Methods, \\ Social and Humanitarian Disciplines Department Bila Tserkva \\ Institute of Continuous Professional Education \\ Bila Tserkva, Kyiv region, Ukraine \\ https://orcid.org/0000-0003-1649-3789 \\ shchypska@ukr.net
}

\begin{abstract}
The modern model of socio-economic development of Ukraine must meet an effective system of vocational and professional higher education, which can quickly adapt to market demands and provide training for skilled workers who are able to be competitive in the existing socio-economic space.. In recent years, a change in the educational paradigm is taking place in the state: from information-cognitive, inherent in industrial society, to personal-activity, based on a competency-based approach to the educational process, characteristic of the post-industrial, information society. Educational practice objectively needs to make a particular student the main figure in the educational process, thus focusing
\end{abstract}


the activities of teachers of vocational education on the personification of the process of professional training. Significant changes in society, social life, the productive sector of the economy and the sphere of state services necessitate the training of a pedagogical worker with a fundamentally new type of thinking. An employee who is ready to carry out innovative pedagogical and scientific-methodical activities, professionally competent, who is able to perform constructive actions in various situations of a professional nature and carry out educational and methodological activities at a high scientific level in accordance with modern educational requirements.

The article presents the main approaches to the development of professional competence of a teacher of the system of vocational and professional higher education. One of the leading components of professional development of a teacher is his ability to modern educational and methodological activities, which involves designing classes based on a competency approach, the use of innovative educational technologies, the introduction of integrated learning in the system of vocational education.

Keywords: integration in education, competence approach in education, educational technology, professional competence, educational and methodical competence, technological approach in education.

\section{INTRODUCTION}

Education, as one of the most important components of society, on the one hand, depends on the processes taking place in it, and therefore must respond quickly and meet the state of scientific and technological progress, trends in the economic sphere of the country. On the other hand, education certainly affects all processes and aspects of society, as it prepares professionals for various fields, develops the personality of students, and forms their certain social and life views. In this context, special attention is paid to the development of methodological competence of pedagogical workers of vocational education, their readiness for continuous professional development. As stated in the Concept of implementation of state policy in the field of vocational education "Modern vocational education" for the period up to 2027, one of the problems is the inconsistency of educational content and teaching methods to modern labor market and individual needs (Concept, 2019). The current state, prospects and problems of innovation in education in our country, the willingness of the teaching community to accept and implement them in their professional activities is an important point in the implementation of the tasks of reforming vocational education.

Modern education today is forced to be on the crest of innovative change, and at the same time remains a traditional institution of socialization, sanctioned by the state and designed to fulfill the public order. However, when the social order for vocational education and the content of this education change, it is difficult for teachers of vocational schools. They, for the most part, are accustomed to using traditional forms and methods of educational, organizational, and scientific-methodical activity in their practice, to lead their pedagogical activity in accordance with educational innovations. Modern education today is forced to be on the crest of innovative change, and at the same time remains a traditional institution 
of socialization, sanctioned by the state and designed to fulfill the public order. However, when the social order for vocational education and the content of this education change, it is difficult for teachers of vocational schools, who, for the most part, are accustomed to using traditional forms and methods of educational, organizational, and scientific-methodical activity in their practice, to lead their pedagogical activity in accordance with educational innovations.

The purpose of the article is to highlight the essence of educational and methodological competence of a modern teacher and vectors of its development in the planning, organization and implementation of the educational process in institutions of vocational and professional pre-higher education.

\section{THEORETICAL FOUNDATIONS}

The problem of development of educational and methodical component of professional competence of pedagogical workers of the system of professional-technical and professional higher education is in the center of attention of researchers. Because this component of the activity of a modern teacher plays a leading role in the process of modernization of national education.

V. Vvedensky, M. Zhaldak, I. Zyazyun, N. Nychkalo, M. Kornilova, O. Lokshina, L. Vashchenko, O. Ovcharuk, O. Pometun, O. Savchenko, S. Sysoeva O. Semenog, E. Azimov, N. Bibik, L. Karpova, M. Kademiya, A. Kolomiets and others systematically researched the development of professional competence of a teacher.

A number of modern scientists-educators (V. Sidorenko, V. Kovalchuk, L. Orshansky, A. Vitchenko, I. Clark, L. Liktey, V. Adolf, N. Tarasenkova, O. Nikolaev, S. Skvortsova, I. Malova, I. Zaichenko, I. Akulenko, O. Lebedeva, O. Zubkov, T. Gushchyna, T. Rudenko, L. Mitina, L. Sherstyuk, J. Gayevets, J. Tsymbalyuk, etc.) distinguish methodological competence as one of the main components of professional development of teachers.

Publications by S. Bolsun, R. Gurevych, L. Danylenko, N. Nychkalo, V. Oliynyk, L. Petrenko, V. Radkevych, L. Sergeeva, N. Chypylenko, L. Shevchuk and others are devoted to the problem of development of creative potential of a modern professional teacher. Education, creating a positive image and readiness to implement innovative educational and methodological activities

\section{RESULTS AND DISCUSSION}

Competence approach, which is becoming important, is recognized as one of the priority areas of modernization of education in Ukraine. Because it shifts, the emphasis from the process of accumulation of normatively defined knowledge, skills and abilities in the plane of formation and development of students' ability to act practically and creatively apply the acquired knowledge and experience in different situations. In view of this, the urgent tasks that need to be addressed urgently are the replacement of the educational paradigm from a system focused on the teacher as a "knowledge repeater" to a system focused on the learner, according to which the teacher acts as an organizer of educational activities. Student behavior (student, listener) varies from passive learning to research-active, 
independent and self-educational activities. Therefore, the competence approach can be considered an alternative to the educational process, built on the basis of the didactic triad "knowledge - skills - skills", in which there was a problem of separation of knowledge from the ability to apply them. The introduction of a competency approach to the vocational education system is accompanied by improved interaction with the labor market, increased competitiveness of professionals, updating the content, methodology and appropriate educational environment.

Competence approach is the focus of the educational process on achieving integrated learning outcomes, which are general (basic, key) and special (subject) competencies of students. General (basic, key) competencies ensure the continuity and consistency of learning throughout a person's life. They are gradually deepened and enriched depending on the level of education. In the system of vocational and professional pre-higher education there are general (basic, key), and professional (related to specialty and specialization) competencies (Vitchenko, 2019).

In pedagogy, the competency approach is defined as "a set of interrelated concepts, ideas and methods of pedagogical activity", "methodological tools for solving complex problems", conceptual, mutually agreed views on the target guidelines of teaching and education, ways and means of their implementation under certain conditions. Educational policy, educational environment, etc.). Therefore, the competence approach in vocational education should be understood as a unity of the following leading provisions:

- focus on achieving integrated training indicators for future professionals;

- systematic acquisition of the main groups of competencies - general (key), professional and professional;

- dependence of the system of competencies on the level and degree of professional education, its gradual complication, renewal and enrichment;

- focus on socialization and professionalization of the individual, the constant deepening (improvement) of competencies in continuing education.

The fundamental difference between the competence educational paradigm is the target orientation of professional education, the values of the subjects of study, the expected results of educational and professional training of future professionals. In accordance with the realities and needs of the information society, the competence-oriented vocational school abandons the outdated practice of transferring and reproducing ready-made knowledge, directs all participants in the educational process to achieve integrated indicators in personal and professional development, which means competencies (Clark, 2015).

Competence approach in education is aimed at the formation of competencies as manifestations of awareness of the teacher in certain issues, skills of practical application of knowledge, values to themselves, others and the environment.

Competence is a modern dimension of human education, when the first place is given not to the amount of material studied, but to the result, embodied in the ability to act in different conditions and circumstances.

A teacher who applies a competency-based approach does not act as a "repeater" of educational material. He acts as a mentor, organizer of educational activities with many opportunities. 
The role of the learner is transformed from passive perception and reproduction of knowledge into research and self-educational activities. He realizes that the key to success is the desire for self-development and positive motivation.

The term "competence" has also become widely used in defining such an integrated quality of a teacher as professionalism. In the International Quality Standard, adopted in Ukraine as a state (State Standard of Ukraine ISO 2000-2001), competence is defined as "the availability of appropriate education, training, qualifications and experience." The Standard of Higher Education of Ukraine defines competence as "knowledge and experience in a particular activity". Professional and pedagogical competence is seen as "the ability of teachers to" transform the learning process into a means of shaping the personality of students "and reflects the ability of a vocational school teacher to quickly, independently and effectively solve current pedagogical problems. Competence is a universal combination of skills, knowledge, abilities, and ways of thinking, valuesand ideological beliefs, which allow you to confidently and successfully get out of various life situations.

In accordance with the basic concepts and definitions of the updated National Qualifications Framework adopted by the Government of Ukraine (Resolution № 519 of 25.06.2020), the integral competence of a specialist is defined as a generalized description of the qualification level that expresses the main competence characteristics of the level for training and / or professional activity.

Its main indicators determine the professional competence of a teacher: readiness for educational and scientific-methodical activities, personal pedagogical skills, innovative thinking, and professional prognostic skills. The professional competence of a teacher consists of scientific-professional, methodological, socio-psychological, differentialpsychological, reflexive, superdisciplinary (key ",' basic) competencies.

The essence of educational and methodical activity is to master the knowledge available in science, the formation of skills, abilities and concepts, the study of the practice of teaching experienced colleagues and recognized in the world pedagogical science professionals.

Educational and methodical competence is a system of methodical knowledge, skills, abilities, competencies of a teacher, connected with the methods of teaching a specific academic discipline; sufficient level of mastery of specific techniques, methods, techniques and means of pedagogical activity, which depends on the inclusion of students in various types of cognitive activities and the development of the study group (Tolochko, 2019).

Educational and methodological competence is one of those competencies that are recommended by European conventions, as it provides for independence and responsibility. The stage of professional methodological development of pedagogical workers of vocational education institutions presupposes their ability to choose technologies and methods of conducting educational activities on the basis of their own experience. At the same time, modern methodology dictates pedagogical conditions, where the teacher acts as a facilitator (consultant), who is able to solve professional problems regulated by his own activities. At the same time, when choosing methods autonomously, it is important to keep in mind the professional requirements for teaching professional disciplines (Liktey, 2020).

The teacher's focus on creating his own methods, willingness to optimize methodological projects, experimental research, modern educational technologies and methods of teaching 
general and special disciplines, obtaining new results in educational, organizational, and methodological activities is based on the development of his teaching and methodological competence.

Any educational concept, including the concept of a competency-based approach to vocational training, is implemented through a complete system of actions. If this system is quite variable and flexible, it is called a teaching method. If there is a more or less clear algorithm and the final result is guaranteed with a reliably estimated probability, this educational system is called learning technology. In other words, the technological approach to learning is the introduction of a systematic way of thinking in pedagogy. This approach to educational and pedagogical processes allows: to provide accurate instrumental, methodological, communicative management of the educational process; significantly increase the probability of achieving the predicted result; scientifically substantiated to analyze and systematize the existing practical experience and its use; make optimal use of the real situation on available resources, reduce the impact of adverse circumstances on the participants of the educational process and create conditions for personal development; choose the most effective and develop new advanced technologies of training and production process to solve problems.

According to UNESCO, educational technology is, in general, a systematic method of creating, applying and defining the whole process of teaching and learning, which takes into account human and technical resources, their interaction and aims to optimize forms of education.

Optimization of the educational process is understood as the choice of such a technique, the application of which will lead to the best results with the minimum necessary time and effort. Optimization involves the most effective (optimal) course of the pedagogical process in terms of given criteria based on a comprehensive account of patterns, principles, modern forms and methods of teaching and education, existing conditions and characteristics of teachers and students (Kaplunovsky, 2005).

Educational technology can be considered as a pre-designed learning process with clearly defined functions of teachers and students at each stage of this process, which with a high level of probability leads to the achievement of a guaranteed result. The algorithm for managing this process can be a kind of scenario (project), which reflects the implementation of the content of technology through the use of a system of techniques, methods, forms of organization and learning tools to achieve the planned goals.

The technological approach in education contributes to the introduction of a systematic approach and covers a wide range of theoretical and practical issues of management, organization of the educational process, the introduction of innovative forms, methods, tools and technologies of teaching. This approach frees the teacher from arbitrariness in planning the learning process and allows you to purposefully achieve the predicted end result, provided a clear justification of each stage and components of the learning process. The technological approach in teaching the profession allows to comprehensively solve educational and upbringing goals, choose the most effective technologies and models of teaching to solve emerging pedagogical and methodological problems, analyze and systematize on a scientific basis the existing pedagogical experience of optimizing the educational process. 
Implementation of competence and technological approaches in education are the main vectors of development of educational and methodological competence of a modern teacher of a vocational school.

Competence lesson is a lesson of personality-oriented, activity, creative. Designing a competency lesson is a transformation of its content component into a means of achieving the main didactic goal and planned results.

The competency approach to such a lesson is focused on the organization of educational and cognitive activities of students by using of interactive educational technologies in the educational process. With this approach, preference is given to creative pursuits, the main task of which is to organize productive active activities of students.

The main characteristics of the competency lesson are (Pometun, 2018):

- lack of a strict algorithm for conducting classes, assuming situationality in its didactic structure;

- providing students with the opportunity to choose the path and trajectory of learning new knowledge, skills and abilities;

- effective use of interactive, exploratory and research teaching methods;

- the possibility of diversifying approaches and points of view to the coverage of educational material and its competent interpretation;

- use of reflection, self-presentation and protection of students' creative product instead of external control.

The specificity of the competency lesson is that students do not learn "ready knowledge" offered by the teacher, and trace the conditions of origin of this knowledge. It is implied that the pupil (student) forms the concepts necessary to solve a particular problem himself. In this approach, the educational activities of the learner, who periodically assumes the role of researcher or practice-converter, itself becomes the subject of assimilation. In such training, the student learns new types of experience: identifies and identifies problems, acquires research and design skills, cooperation, applies known and creates new technologies for acquiring knowledge.

The organization of a competence lesson focused on the result begins with a clear awareness of the teacher of the desired level of academic achievement of students. The teacher should strive to formulate clear, understandable, real, measurable results as a separate lesson, and the study of a topic, section or course. Therefore, instead of a vague goal setting at the initial stage of the teacher's lesson, it is necessary to determine the expected learning outcomes, which is a mandatory and important procedure, because without it, the effective application of a particular model of learning (forms, methods, technologies, tools, etc.). In addition, the expected learning outcome is always the level of educational knowledge and skills achieved by students, for the formation and development of which such conditions were created during the lesson. Reflection acts as a method of finding out how and how other participants in the educational process understand the teacher, his personal qualities, emotional reactions, professional abilities and capabilities.

Reflection is understood as a specific form of theoretical activity aimed at understanding and analyzing one's own actions. It is very important for the teacher to establish to what 
extent the obtained results (positive or negative) are a means of successful activity of students in the process of mastering the profession.

Reflective skills of students take place in the implementation of their control and evaluation activities aimed at themselves, and involve the use of such varieties as: control based on the correlation of the results with the given samples; control based on the expected results of actions performed only mentally; control based on the analysis of the finished results of the actions actually performed. Reflection is not just knowledge or understanding of the subject of pedagogical activity himself, but also finding out how and how other participants in the educational process know and understand his personal characteristics, emotional reactions and professional abilities and capabilities.

Teacher's ability to design a competency lesson (Shevchuk, 2021):

- analytical (reflection of each stage of the competence lesson, analysis of the results of educational activities of students);

- prognostic (goal setting, design, planning, modeling, etc.);

- psychological (mastering the basic pedagogical and psychological diagnostics);

- organizational (managerial).

Competencelessonininstitutions of professional (vocational) education is also characterized by the fact that it solves the problem of motivation of educational activities of students of vocational education. In such a lesson, a model of "learning with enthusiasm" is created. This is, first of all, a lesson in which the teacher skillfully uses all pedagogical opportunities for the development of the student's personality, his active intellectual growth, deep and meaningful acquisition of knowledge in order to form a competent personality. The didactic structure of the lesson is formed in accordance with the type of lesson. The methodical substructure of the lesson, which depends on the methods of its conduct, in contrast to the didactic is a variable and is characterized by greater variability, reflects the main stages of learning and the active nature of the educational activities of students in the classroom.

Based on the above, the competency lesson may contain certain dynamic fields that the teacher can effectively saturate according to their level of professional competence: content, motivation, field of goal setting, technological, reflective, and emotional.

Competencelesson is, firstofall, an interactivelesson. Interactivityis an enhanced pedagogical interaction, the mutual influence of participants in the pedagogical process through the prism of their own individuality, personal life experience. This interaction is characterized by a high degree of intensity of communication of its participants, their communication, exchange of activities, change and diversity of its types, forms and techniques, purposeful reflection by participants of their activities and interactions. The purpose of the interactive process (interaction between the subjects) - change and improvement (improvement) of models of behavior and activities of participants in the learning process.

Therefore, interactive learning is learning in the mode of enhanced pedagogical interaction of participants in the educational process in order to jointly solve educational problems and develop personal qualities of students (Shevchuk, 2021). Interactive learning is based on a new philosophy of constructivism and postmodernism, which becomes the methodological basis of modern educational policy. The main ideas of this philosophy in vocational training are reduced to the need to train responsible, creative, active workers who respect diversity, dialogue of 
cultures, creative interaction. Innovative learning technologies should be based on the active cooperation of teachers and students, their cooperation in the learning process.

Today we can say that in Ukrainian pedagogy a wide range of interactive methods and practices in the classroom are adapted, theoretically sound and involved in the practice of teachers of vocational schools. These are such techniques as situational modeling, interactive training, educational discussions, business and role-playing games, etc. Interactive techniques allow applicants for vocational education:

- thoroughly analyze educational information and creatively approach its assimilation, make the process of assimilation and application more accessible;

- learn to formulate their own opinion, to express it correctly, to prove their point of view, to argue and discuss;

- model and solve cognitive, professional, social and life situations, thus enriching their own cognitive and social experience;

- learn to build constructive relationships in the student group, determine their place in it, avoid conflicts, seek compromises, seek dialogue, find a common solution to the problem;

- to develop skills of project activity, independent work with various sources of information, performance of creative tasks, etc.

The ideas of competence education are inextricably linked to the problems of integration in education. Researchers of these problems argue that integrated learning is fundamentally important for the formation of professional competence of the future skilled worker, and for his future professional activity.

Integration in education is a process (bilateral, systemic and structural) of interpenetration, consolidation, unification of knowledge; establishing the integrity of the content of education; establishing connections between relatively independent things, processes, and phenomena. When these connections are significant, they determine the functioning of the phenomena to be integrated; combining elements that are accompanied by the complication and strengthening of ties between them, the interpenetration of elements of a holistic system, the transition from one form to another; historical movement of knowledge towards unity; interpenetration of information from one training course to another (Rudnytska, Tarnavska, 2018).

The essence of educational integration is to implement the processes of unification of all components of the pedagogical process (content, forms, and methods), which causes: the expansion of educational functions (integrative function); innovative learning (innovative function); modernization of education (integrated technologies); new learning outcomes (comprehensively developed personality).

Integration processes are aimed at the realization of new educational goals - the formation of a holistic system of knowledge and skills of the individual, the development of his creative abilities and potential.

Integrated classes are an interdisciplinary combination of classes aimed at comprehensive knowledge of the topic, laws, and ideas in order to provide students with a deeper understanding of a particular educational or problem situation.

The essence of integrated classes in vocational education institutions is that it is planned, organized and conducted by several teachers (teachers and masters of industrial training). A binary lesson is a type of integrated lesson taught by two teachers. 
The peculiarity of conducting an integrated lesson is in the combination of blocks of knowledge in different subjects, subordinated to one topic of the curriculum. Therefore, it is very important to clearly define the main purpose of the integrated lesson, how this lesson will contribute to the integrity of learning, the formation of students' knowledge at a qualitatively new level.

Integration technology is extremely effective in the training of skilled workers. Meaningful and purposeful integrated classes bring novelty, originality to the traditional structure of vocational education, contribute to the formation of a holistic system of professional knowledge and skills and integrated competence of students, creating favorable conditions for mastering the profession.

Methodologically correct planning, construction and conduct of integrated classes in institutions of vocational and professional higher education contribute to improving the educational and methodological competence of teachers of vocational schools. Because it requires a high level of professionalism, mastery of methods of implementing modern educational practices in the educational process.

The lesson was and remains the main form of professional training, but the extracurricular form of organization of educational and cognitive activities of students in vocational and professional higher education is no less important in their activities, because it allows all subjects of educational activities to expand the scope of interaction for the development of search, research and creative activities. A wide range of didactic and educational goals inherent in the classroom form, are characteristic of extracurricular. These are: implementation of the basic principles of didactics; compliance of the content of education with the current level of scientific achievements in the field; effective and efficient use of innovative educational technologies; ensuring high educational and cognitive activity of students in the process of solving specific and problematic problems of educational, industrial and social nature; rational alternation of different types of activities of students; providing prompt feedback; providing timely operational counseling by teachers and professionals; positive influence on the motivational sphere, stimulation and formation of positive attitude to lifelong learning in students, their independence and creative abilities; development of communicative qualities of students. All the above-described forms, methods and means of activity of the teacher are inherent in the innovative extracurricular educational and organizational work of the teacher of the vocational school. However, the main purpose of such activities is still to focus on the formation of future skilled workers' knowledge, skills and abilities of individualization and differentiation in their search, research and creative activities.

The expansion of the range of educational innovations has led to their penetration into all levels of educational activities, where they are successfully used to increase the efficiency of the educational process. In particular, they are used in extracurricular educational activities, which in vocational (technical) education is one of the main forms of organization of the educational and production process, used in classroom and independent activities of students, is part of the professional competence of teachers, forms and develops methodological competence.

Extracurricular educational activities are closely related to the additional education of future professionals, when it is combined with the development of their creative interests 
and their inclusion in other areas of activity. As you know, additional education of the future specialist is an organic part of the system of education and upbringing, which is focused on the free choice and use of additional educational programs by applicants for educational services. The main purpose of additional education in the process of extracurricular activities is to develop the motivation of subjects of educational activities to cognition and creativity, their personal and professional self-determination, and adaptation to life, society, involvement in a healthy lifestyle (Shevchuk, 2021).

\section{CONCLUSIONS}

One of the main tasks of reforming the system of vocational and professional higher education in Ukraine is the training and development of highly qualified pedagogical staff. Teachers for whom educational and methodological competence is an important aspect of professional and pedagogical development. This approach will solve the problem of inconsistency of teaching methods to the requirements of the modern labor market and the needs of the individual, as stated in the Concept of state policy in the field of vocational education "Modern vocational education" for the period before 2027.

Solving the problem of improving the quality and efficiency of the educational process in the domestic system of vocational and professional higher education is closely related to the above outlined vectors of development of the level of educational and methodological competence of modern teachers in the modernization of vocational and professional higher education in the educational process of institutions of professional education of competence, technological and integration approaches. It is the implementation of these areas will be the key to the deployment of innovative processes in the system of vocational education, which today is a priority area in the socio-economic, spiritual and cultural growth of Ukrainian statehood. It is through changes in the activities of teachers with a focus on educational innovation and its readiness to realize personal creative potential that we can achieve qualitative changes in the educational process of vocational and professional higher education, bring the results of their activities to the standards of the European educational space.

\section{REFERENCES}

Vitchenko, A. O., Vitchenko, A. Yu. (2019) Competence Approach in Modern Higher Education: Educational Innovation or Reformist Simulacrum of the Postmodern Era. Vyshcha Shkola. 4 (177). 52-66.

Kaplunovsky, R. (2005) Optimization of the Pedagogical Process. Education. Technical Schools. Colleges. 1 (11). 14-15.

Clak, I. E. (2015) Theoretical Principles of the Competence Approach in the System of Higher Professional Education. Bulletin of Chernihiv National Pedagogical University. Series: Pedagogical sciences. 124. 32-34.

The Concept of Implementation of state Policy in the Field of Vocational Education "Modern Vocational Education for the Period up to 2027": Order of the Cabinet of Ministers of Ukraine from 12.06.2019 № 419-r. Access mode: https://zakon.rada.gov.ua/laws/show/419-2019-\%D1\%80\#Text

Liktei, L. M. (2020) Current State of Development of Methodological Competence of Teachers of Humanities Disciplines of Pedagogical Colleges. Pedagogy of Formation of Creative Personality in Higher and Secondary School. 68, Vol. 1. 82-85. 
Pometun, O. I. (2018) Competence-Oriented Methods of Teaching History in Primary School: a Manual. Kyiv: LTD «KONVI PRINT», 208 p.

Rudnytska, N., Tarnavska, N. (2018) Didactic Essence of Integration and Ways of Its Realization in the Learning Process. Youth and the Market. 7 (162). 46-51.

Tolochko, S.V. (2019) Concept and Methods of Formation of Scientific and Methodological Competence of Teachers in the System of Postgraduate Pedagogical Education: Monograph. K.: National Pedagogical Dragomanov University, 376 p.

Shevchuk, S. S. (2021) Educational and Methodical Activity of a Teacher of Vocational Education Institutions on the Basis of the Competency Approach: a Textbook. Bila Tserkva: BICPE SIHE «University of Education Management» NAPS of Ukraine, 73 p. 